soft compressible pulse. To verify my diagnosis to the matron of the asylum, I lifted her arm in mid-air, and releasing my hold, it remained until I forced it down by some little pressure; and likewise I elevated her right foot with the identical result. The general rigiditas corporis was typical, just as instantaneous; she would utter a piercing shriek as if in pain, and toss about violently, and subside into a low moaning condition, ultimately in to a comatose state; when not violent in her seizures she would alternately laugh, cry, and talk at random. Even the freely appearing menses would not cause an immediate arrest of the phenomena, yet to facilitate the How, I would have stüpes (of turpentine and hot ziater, $3 \mathrm{j}(\mathrm{Oj}$ ) applied to whole surface of abdomen, repeated conformably to her tolerance and restoration. During the first attack, I gave her $1 / 2$ gr. morph. sulph. hypodemically, with controlling benefit, shortening the the attack. The second attack was controlled by chloral and bromide of potash compounded in enema opii, repeated as indicated. In each of her attacks or seizures, the duration was four or five days before perfect restitution was effected, and save an extreme prostration subsequently she suffers no inconvenience. She is now at her post, and upon the next seizure, I will make more minute notes as to pulse, temperature, character of urine as also exact duration of attack from incipiency to termination. I have placed her upon a strictly tonic treatment.

George W. Monette, M. D.

285 Camp street, New Orleans, June zo, 1885.

\section{THE INTERNATIONAL CONGRESS COMMITTEE.}

Eidior Jolrnal American Medicat Associatiox.

Dear Sir:-I notice in the report, as published in the Joursal, of the proceedings of the meeting of the Committee of the American Medical Association on the International Medical Congress, that my name appears among those present at the meeting. I was not present, and I do not approve of what was done at the meeting. Yours truly,

Orange, N. J., July 8 , I 885 .

Wa. Pierson.

\section{HYDATID TUMORS OF THE BRAIN.}

Sir:-Allow me to call attention to two points in the paper by Dr. R. Harvey Reed, on "Hydatid Tumor of the Brain," published in the Jocrnal of July $4^{\text {th. }}$ (I) The term hydatid tumor should be, and usually is, limited to the echinococcus cyst, the larva of the Tienia echinococcus or Hydatid tapeworm. The terms "cysticercus" or "measle" should be used in describing the larva of the Tania solium. (2) The cases reported by I)r. Reed cannot as they stand be accepted as instances of hydatids or of cysticerci. The description of the cysts is too meagre, and a microscopical examination does not appear to have been made, without which it is in many cases impossible to determine the parasitic an nature. From the position of the cysts in the lateral tris ventricles in each case, it seems probable that Dr. Reed has been dealing with the not tuncommon hydatidiform cysts of the choroid plexuses, structures which have on several occasions been sent to me as possibly parasitic.

Interest in the subject of echinococcus disease in this country must be my excuse for thus encroaching on your space.

University of Pennsylvania, July $7, \mathbf{1} 885$.

WIIIIAM OSLER.

\section{NECROLOGY.}

\section{WILLIAM T. WRAGG, M. D.}

'The custom of commemorating, in some form, the death of one who has impressed his fellows by his virtues or his actions is of very ancient date, and its continuance at present is not only evidence of its propriety, but of its filling a want that the mind of every person admits to exist. In reviewing the life of him who so lately has been taken from amongst us, one cannot fail to be reminded that death has removed from our ranks a faithful, efficient and esteemed brother; one who loved the profession, sought its advancement and respected all its usages.

On the 3 oth of May, I885, I3r. William 'T. Wragg, one of the oldest and most esteemed physicians of the State of South Carolina, died at his residence in the City of Charleston, S C. He was born near Creorgetown, S. C., removed with his parents, Major and Mrs. Samuel Wragg, to Charleston in r8r9. He entered the South Carolina College, where he graduated in 1827. He chose the medical profession as his pursuit through life, entered the office of J). J. M. Campbell as a student, and attended the "Medical College of the State of South Carolina" for three years, graduating at that institution in March, I830. In the following May he went to Paris with Dr. J. E. Holbrook, professor of anatomy in this college, where he pursued his medical and surgical studies, and after visiting all the hospitals, made the wards of Hôtel Dieu his constant care; every day found him in attendance at the visits and clinique of the greatest surgeon and diagnostician of his age, Dupuytren. Here also lectured at that time the great physiologist and vivisector, Magendie. A few weeks after his arrival the famous revolution of July, 1830 , broke out, and hundreds of men, women and children filled the wards of Hotel Dieu, with every kind of wound, gunshot, sabre, bayonet, cannon ball, and wounds from stones and other missiles. Here Dr. Wragg learned those lessons which gave him success in his practice in after years.

Soon after his return home, Dr. Wragg entered upon the practice of his profession, and continued it successfully to the time of his death. In $\mathrm{x} 847$, Dr. Wragg was made treasurer of the "Roper Hospital Fund," a fund bequeathed to the Medical Society of South Carolina by Mr. 'Thomas Roper with which to build a hospital. His administration of this office shows how careful he was of trust reposed in him, and how his judicious management has enabled the trustees to execute the testator's benevolent intentions. The fund was under Dr. Wragg's management from 1847 to the day of his death -37 years- 